\title{
Specialet som glasloft \\ - hvorfor får mandlige studerende bedre specialekarakterer?
}

\author{
Vibeke Lehmann Nielsen, lektor ved Institut for Statskundskab, Aarhus \\ Universitet samt seniorforsker ved SFI. \\ Lotte Bøgh Andersen, lektor ved Institut for Statskundskab, Aarhus \\ Universitet samt Anvendt Kommunal Forskning (AKF). \\ Michael Bang Petersen, lektor ved Institut for Statskundskab, Aarhus \\ Universitet.
}

\section{Reviewet artikel}

Selvom de mandlige universitetsstuderende ikke klarer sig bedre end kvinderne frem til specialet, fär de gennemsnitligt bedre specialekarakterer. Artiklens analyser viser, at det hverken handler om specialevejlederens køn eller om typen af universitetsstudium. Mulige forklaringer, som det er værd for kommende forskning at forfølge, er dels generel diskrimination af kvindelige specialestuderende og dels de studerendes møde med specialet, hoor kønnenes livssituation og/eller deres reaktioner på rollen som specialestuderende kan være forskellige.

\section{Indledning}

Empiriske data fra 2291 universitetsstuderende ved Aarhus Universitet viser, at mandlige studerendes karaktergennemsnit for specialet er 9,4, mens kvindelige studerende i gennemsnit får 9,1 for specialet (begge dele er kontrolleret for, hvilket studium de læser). Det er et tankevækkende resultat, især fordi der ikke er forskel frem til specialet, hvor gennemsnittet for begge køn er 8,1 (igen kontrolleret for studium). Nærværende artikel undersøger, hvorvidt kønsforskellen i karakterer for specialet hænger sammen med vejlederens køn, eller om kombinationen af hhv. mand$\mathrm{lig} / \mathrm{kvindelig}$ vejleder og mandlig/kvindelig studerende har betydning.

Først argumenter artiklen for, hvorfor vejlederkøn og kombinationen af vejleder- og studenterkøn kunne tænkes at have betydning for, at de mandlige universitetsstuderende opnår højere specialekarakterer end de kvindelige studerende. Derefter undersøges forklaringen under anvendelse af registerdata for 2291 studerende fra 11 insti- 
tutter på Aarhus Universitet, og endelig diskuterer vi analyseresultaterne og andre mulige forklaringer.

\section{Betydningen af vejlederens køn}

Der findes kun få studier, der fokuserer på kønnets betydning for vejledning på universiteter (Wichmann-Hansen, Eika \& Mørcke, 2007: 15), men Zegers argumenterer for, at sprogbrugen på universiteterne er maskulin, og at kvinder i vejledningssituationer sprogligt bliver kategoriseret som en social gruppe med mindre magt (2004: 23). Johnson, Lee \& Green (2000: 146) argumenterer i forlængelse heraf for, at der er konflikt mellem kvinders kønsbetingede identitet og den identitet, de forventes at påtage sig som studerende i vejledningssituationer. Argumentet er, at forestillingen om den autonome forsker (dvs. i denne sammenhæng den meget selvstændige specialestuderende) betyder en afvisning af "kvindelige værdier" såsom følelser, personligt engagement og gensidig menneskelig afhængighed. Det kan være en ulempe for kvindelige specialestuderende, især hvis de har mænd som vejledere. Hasse og Trentemøller (2008) finder i forlængelse heraf, at kulturelle mønstre på universiteterne (helt specifikt fysikinstitutter) giver mænd og kvinder forskellige vilkår.

De ovenstående argumenter for, at kvinder har sværere end mænd ved specialeprocessen (i dens nuværende form), kan være forbundet med, at de fleste vejledere er mænd. De eksisterende studier af vejledningsstil peger da også på, at mandlige og kvindelige specialevejledere opfører sig forskelligt. Jensen (2010: 19) fandt fx, at mandlige vejledere talte fire femtedele af tiden under specialevejledningerne, mens kvindelige vejledere kun talte knap tre femtedele af tiden. Der er flere argumenter for, at kombinationen af den studerendes køn og vejlederens køn kan forklare kønsforskelle i forbindelse med specialet, men de peger ikke alle i samme retning.

Et klassisk argument i kønsforskningen kaldes Rip-Rap-Rup-effekten og betegner (især mandlige) lederes tilbøjelighed til at foretrække personer, der ligner dem selv (dvs. mænd). Måske klarer mandlige specialestuderende sig derfor bedre end kvindelige specialestuderende, fordi de mandlige vejledere bedst får øje på de kvalifikationer, som er forbundet med mandekønnet (Højgaard, 1996; Andersen, Bloksgaard \& Christensen, 2009: 71). Idet de fleste vejledere er mænd, kan det potentielt forklare forskellen, selvom kvindelige vejledere må forventes at have den modsatte adfærd (en Kylle-Pylle-Rylle-effekt). Uddannelsesforskningen diskuterer betydningen af lærerens/vejlederens køn lidt anderledes. Her differentieres der mellem passive og aktive lærereffekter (Dee, 2005: 159). Rollemodeltesen forventer en positiv passiv effekt på de studerendes akademiske motivation og forventninger alene på baggrund af tilstedeværelsen af en lærer/vejleder af samme køn. De aktive lærereffekter minder om kønsforskningens forventninger, idet disse udgøres af "unintended bia- 
ses in [teachers'] prior expectations of and interactions with students who have different demographic traits" (Dee, 2005: 159). Implikationen af alle argumenterne er, at mandlige specialestuderende med mandlige vejledere og kvindelige specialestuderende med kvindelige vejledere skulle forventes at klare sig bedre end kombinationerne af mand og kvinde.

Det er imidlertid ikke givet, at de mandlige specialevejledere er skyld i, at de kvindelige studerende mister terræn i forhold til de mandlige i forbindelse med specialet. Hvis man kigger socialpsykologisk på specialevejledningen, kunne man modsat argumentere for en forventning om, at mandlige vejledere faktisk tager sig mere af deres kvindelige end af deres mandlige studerende. En række studier af mænds sociale adfærd har således demonstreret, at mænd er særligt tilbøjelige til at hjælpe kvinder, hvilket fortolkes som et ubevidst forsøg på at tiltrække partnere. Dette gælder især unge, attraktive kvinder (se Buss, 2011: Kapitel 5 og 6).

Omvendt er det ikke umuligt, at de kvindelige vejledere lader deres kvindelige specialestuderende mere i stikken end deres mandlige specialestuderende. Litteraturen bruger betegnelsen "Queen bee syndrome" (bidronningesyndromet) om det fænomen, at kvindelige autoriteter skulle behandle kvindelige underordnede mere kritisk end mandlige underordnede (Staines, Tavris \& Jayaratne, 1974; Ellemers et al., 2004). Bidronningesyndromet kunne forklare, at kvindelige studerende bliver overhalet af mændene under specialeprocessen. Implikationen ville være, at kombinationen af en kvindelig studerende og en kvindelig vejleder giver dårligere karakterer end de tre andre kønsmæssige kombinationer. Og eftersom kvindelige studerende i højere grad søger mod kvindelige frem for mandlige vejledere, kunne dette forklare, at de kvindelige studerende gennemsnitligt set får lavere specialekarakter. ${ }^{1}$. Det er imidlertid vigtigt at være opmærksom på, at en del undersøgelser påviser, at kvinder i hvert fald ikke altid opfører sig som bidronninger (fx Ragins \& Scandura, 1994).

Alt i alt har vi fire bud på forklaringer knyttet til vejlederens køn: (1) Den maskuline dominans på universiteterne slår især igennem ved specialet, og kvinder får især dårlige specialekarakterer hos en mandlig vejleder. (2) Specialevejledere prioriterer de specialestuderende, der kønsmæssigt ligner dem selv, og kvindelige specialestuderende med kvindelige vejledere samt mandlige specialestuderende med mandlige

${ }^{1}$ På de 11 undersøgte institutter på Aarhus Universitet har fire ud af fem mandlige studerende mandlige vejledere, mens to ud af tre kvindelige studerende har mandlige vejledere. Forskellen er signifikant $(\mathrm{p}<0,001)$. 
vejledere får bedst karakterer. (3) Kvindelige vejledere behandler kvindelige specialestuderende dårligere end mandlige specialestuderende, hvilket implicerer, at kvindelige specialestuderende med kvindelige vejledere skulle få dårligst karakterer af alle. (4) Mænd prioriterer (af socialpsykologiske årsager) deres kvindelige specialestuderende højere, end de øvrige specialestuderende bliver prioriteret, hvorved kvindelige specialestuderende med mandlige vejledere skulle forventes at få højeste karakterer.

\section{Kvindedominerede studier og mandedominerede studier}

Før vi vender os mod den empiriske undersøgelse, er der imidlertid en vigtig indvending, der skal tages stilling til. Kvindelige og mandlige studerende er nemlig ikke ligeligt fordelt på de forskellige universitetsstudier, og det kunne meget vel tænkes, at det i sig selv forklarer, at mændene opnår bedre specialekarakterer end kvinderne. På naturvidenskabelige studier (hvor der traditionelt har været relativt mange mænd) får de studerende måske ret lave karakterer på bacheloruddannelsen, mens de kan tænkes at ligge på niveau med (eller over) resten af universitetsuddannelserne, når der gives specialekarakterer. For at imødegå denne indvending er det nødvendigt at kontrollere statistisk for, hvilket institut de studerende kommer fra. Næste afsnit kommer nærmere ind på, hvordan dette er gjort, og hvordan undersøgelsen i det hele taget er gennemført.

\section{Hvordan er undersøgelsen gennemført?}

Enhederne i analysen er 2291 universitetsstuderende, der blev færdige med deres universitetsstudie på 11 institutter (jf. tabel 1 nedenfor) på Aarhus Universitet i perioden 2007 til 2010. Fra universitetets registre har vi oplysninger om disse tidligere studerendes specialekarakter og karaktergennemsnit på den øvrige del af deres universitetsuddannelse. Derudover ved vi, om de er mænd eller kvinder, samt hvilket køn deres specialevejleder havde, og hvilket institut de færdiggjorde specialet på. De 11 institutter er udvalg ud fra det simple kriterium, at de var de eneste institutter på Aarhus Universitet, hvor specialevejlederens køn var registeret. Alle karakterer er opgivet på syv-skalaen (alle specialer er afleveret efter syv-skalaens indførelse, og de øvrige karakterer er dermed enten konverteret til eller givet i henhold til syvskalaen).

\section{Hvad viser analyserne?}

Et simpelt gennemsnit af henholdsvis mandlige og kvindelige studerendes specialekarakterer viser, at hvor mænd i gennemsnit bedømmes med karakteren 9,2, bedømmes kvinder i gennemsnit med karakteren 9,0. Denne forskel er dog ikke statistisk signifikant. Der er dog store forskelle mellem de forskellige universitetsstudiers karakterniveau. Da kønsfordelingen som nævnt også varierer på tværs af studierne, 
er det nødvendigt at korrigere kønsforskellen i karakterer for disse forskelle. Efter denne kontrol er karaktergennemsnittet for mænd 9,4 og for kvinder 9,1. Dette udgør en forskel med en statistisk sikkerhed på 99,8 procent. I absolutte karakterer bedømmes kvindelige studerendes specialer altså i gennemsnit lavere end de mandlige studerendes. Et enslydende resultat findes, hvis vi kigger på relative specialekarakterer - hvis vi altså sammenholder specialekarakteren med den studerendes karaktergennemsnit på resten af uddannelsen. Kontrolleres således for den enkelte studerendes karaktergennemsnit på resten af uddannelsen, opnås samme resultat. Selvom en mandlig og en kvindelige studerende har fået samme karakterer indtil specialet, vil den mandlige studerende altså - i gennemsnit - få en højere specialekarakter. Ser vi på karaktergennemsnittene indtil specialet, er gennemsnittet for både mænd og kvinder 8,1, når der er kontrolleret for studium (uafrundet er karaktergennemsnittet for mænd 8,06 og for kvinder 8,08). Kønsforskellen opstår altså i forbindelse med specialet.

I tabel 1 inddrager vi vejlederens køn som en forklarende variabel. Tabellen viser to regressionsanalyser, der begge kontrollerer for de studerendes institut og karaktergennemsnit frem til specialet. Når vi ser på effekten af de studerendes og vejledernes køn, sammenligner vi derfor (billedligt talt) specialestuderende med samme karaktergennemsnit fra samme institut. Model 1 inddrager derudover hhv. vejlederens køn og den studerendes køn separat. Denne kontrol for vejlederens køn ændrer ikke på den allerede observerede effekt af den studerendes køn. Der er stadig en signifikant forskel på mandlige og kvindelige studerende på 0,26 karakterpoint (de tre stjerner viser, at sammenhængen er over 99,9 procent sikker). Spørgsmålet er dog, hvad der sker, hvis man ser på forskellige kombinationer af den studerendes og vejlederens køn. Er kønsforskellen mellem mænd og kvinder eksempelvis kun til stede ved mandlige vejledere (jf. Rip-Rap-Rup effekten)? Dette undersøges i Model 2, hvor de forskellige kombinationer af studerende- og vejlederkøn inddrages. ${ }^{2}$ Figur 1 illustrerer resultaterne fra model 2. Figuren viser, at kvindelige specialestuderende med både mandlige og kvindelige vejledere får signifikant lavere specialekarakterer, når

\footnotetext{
$22 \mathrm{Vi} \mathrm{har}$ analyseret forskellige mere komplicerede modeller for at teste robustheden af vores konklusioner. For det første har vi undersøgt om effekten af karaktergennemsnit indtil specialet har signifikant forskellig effekt på specialekarakteren for mænd og kvinder. Dette er ikke tilfældet og denne modelspecificering ændrer ikke på de præsenterede konklusioner. For det andet har vi undersøgt om effekten af køn er signifikant forskellig på tværs af de forskellige fag. Dette er heller ikke tilfældet. Endelig har vi undersøgt om kombinationerne af vejlederens og den studerendes køn har signifikant forskellig effekt på specialekarakteren for forskellige fag. Heller ikke dette er tilfældet.
} 
der er kontrolleret for såvel institut som karaktergennemsnit for de øvrige karakterer. Tilsvarende er der i model 2 en forskel på 0,30 karakterpoint mellem mandlige studerende med mandlige vejledere (referencekategorien) og kvindelige specialestuderende med hhv. kvindelige og mandlige vejledere. For de kvindelige studerende med mandlige vejledere er forskellen over 99,9 procent sikker, mens den kun er 95 procent sikker for kvindelige studerende med kvindelige vejledere. Der er ikke signifikant forskel mellem mandlige specialestuderende med hhv. kvindelige og mandlige vejledere, og model 1 fandt, som nævnt, heller ikke nogen selvstændig effekt af specialevejlederens køn.

Sammenfattende er der altså ikke forskel på mandlige og kvindelige vejlederes evne til at "løfte" de studerende gennem vejledningen, mens de studerendes køn har en signifikant betydning for specialekarakteren: Mænd får højere specialekarakterer end kvinder, når der tages højde for deres institut og tidligere karaktergennemsnit.

Figur 1. Estimeret specialekarakter for studerende med 7 i gennemsnit på øvrige karakterer.

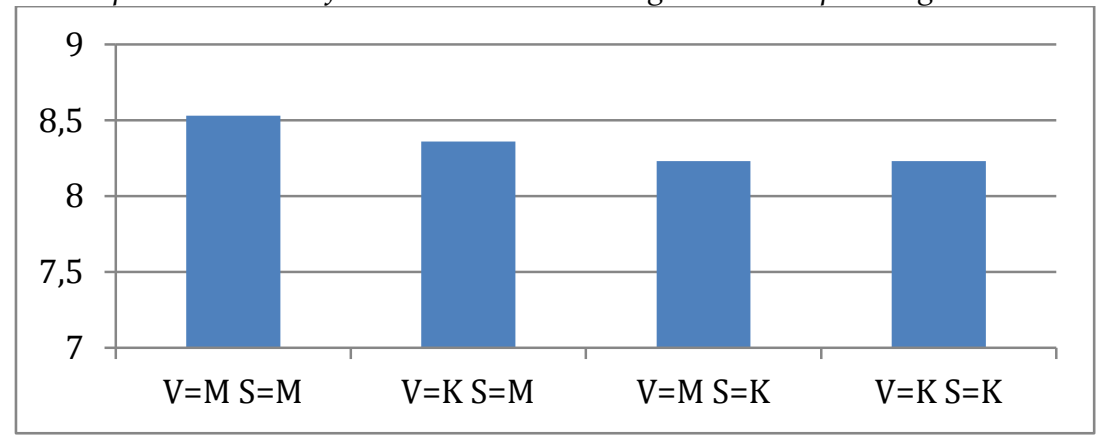

Note: $\mathrm{V}=$ vejleder, $\mathrm{S}=$ studerende, $\mathrm{M}=$ mand, $\mathrm{K}=\mathrm{kvinde}$. Figuren er en illustration af resultaterne $\mathrm{i}$ tabel 1 (model 2) for statskundskabsstuderende med gennemsnit på 7 i øvrige karakterer. Forskellen mellem søjlerne er ikke signifikant forskellig for de øvrige studier eller for studerende med andet gennemsnit.

Yderligere analyser (som kan rekvireres ved henvendelse til forfatterne) viser desuden, at der ikke er nogen sammenhæng mellem de studerendes gennemsnit på den øvrige uddannelse og vejlederens køn. Det er altså ikke sådan, at det ene køn i udgangspunktet får dygtigere specialeskrivere end det andet. Der er heller ikke forskel på mandlige eller kvindelige vejlederes evne til at løfte gennemsnittet fra de øvrige karakterer, og det ene køn er ikke bedre end det andet til at vejlede hhv. bunden og toppen af de studerende. Tabel 1 viser derimod, at der er markante niveauforskelle mellem institutterne, hvilket er udtryk for, at der er variation i, hvor stor forskel der er på øvrige karakterer og specialekarakterer. Der er forståeligt nok også en stærk sammenhæng mellem karaktergennemsnittet frem til specialet og specialekarakteren (1 karakterpoint højere karaktergennemsnit estimeres til at give 0,62 point højere specialekarakter). Det ændrer imidlertid ikke hovedresultatet: Mændene får bedre 
specialekarakterer end kvinderne og det på trods af, at der ikke er forskel på den øvrige del af uddannelsen, og det handler ikke om vejlederens køn.

Tabel 1. Betydningen af vejleders og studerendes køn samt institut for specialekarakteren.

\begin{tabular}{|c|c|c|}
\hline & Model 1 & Model 2 \\
\hline $\begin{array}{l}\text { Konstant (referencekategoriens estimerede speciale-gennemsnit, } \\
\text { hvis gennemsnit på øvrige karakterer=0) }\end{array}$ & $\begin{array}{l}4,17^{\star \star \star} \\
(16,30)\end{array}$ & $\begin{array}{l}4,19^{\star * *} \\
(16,27)\end{array}$ \\
\hline Studenters køn $(\mathrm{M}=0, \mathrm{~K}=1)$ & $\begin{array}{r}-0,26 * \star \star \\
(2,60)\end{array}$ & \\
\hline Vejleders køn (M = 0, K=1) & $\begin{array}{r}-0,06 \\
(0,55)\end{array}$ & \\
\hline Vejleder $=\mathrm{K}$ og studerende $=\mathrm{K}$ & & $\begin{array}{l}-0,30 * \\
(2,16)\end{array}$ \\
\hline Vejleder $=\mathrm{M}$ og studerende $=\mathrm{K}$ & & $\begin{array}{r}-0,30 \text { *** } \\
(2,64)\end{array}$ \\
\hline Vejleder $=\mathrm{K}$ og studerende $=\mathrm{M}$ & & $\begin{array}{l}-0,17 \\
(0,94)\end{array}$ \\
\hline Karaktergennemsnit på den øvrige del af uddannelsen & $\begin{array}{l}0,62^{\star \star \star} \\
(22,70)\end{array}$ & $\begin{array}{l}0,62^{* * *} \\
(22,74)\end{array}$ \\
\hline Biologi & $\begin{array}{r}0,79^{* * *} \\
(3,60)\end{array}$ & $\begin{array}{r}0,80^{\star \star *} \\
(3,63)\end{array}$ \\
\hline Historie og områdestudier & $\begin{array}{r}0,05 \\
(0,22)\end{array}$ & $\begin{array}{l}-0,05 \\
(0,22)\end{array}$ \\
\hline Jura & $\begin{array}{r}-0,19 \\
(1,10)\end{array}$ & $\begin{array}{r}-0,19 \\
(1,07)\end{array}$ \\
\hline Kemi & $\begin{array}{r}1,01^{\star \star *} \\
(2,82)\end{array}$ & $\begin{array}{r}1,02^{\star \star \star} \\
(2,85)\end{array}$ \\
\hline Informations- og medievidenskab & $\begin{array}{r}-0,16 \\
(0,97)\end{array}$ & $\begin{array}{l}-0,16 \\
(0,98)\end{array}$ \\
\hline Molekylærbiologi & $\begin{array}{r}1,50^{\star \star \star} \\
(6,56)\end{array}$ & $\begin{array}{r}1,50^{\star * *} \\
(6,57)\end{array}$ \\
\hline Nordisk & $\begin{array}{c}0,56^{*} \\
(2,58)\end{array}$ & $\begin{array}{r}0,56 * \\
(2,57)\end{array}$ \\
\hline Sprog, litteratur og kultur & $\begin{array}{r}-0,33 \\
(1,70)\end{array}$ & $\begin{array}{r}-0,33 \\
(1,69)\end{array}$ \\
\hline Æstetik & $\begin{array}{r}0,17 \\
(0,95)\end{array}$ & $\begin{array}{r}0,18 \\
(0,96)\end{array}$ \\
\hline Økonomi & $\begin{array}{r}-0,95^{\star \star *} \\
(4,00)\end{array}$ & $\begin{array}{r}-0,96^{\star * *} \\
(4,03)\end{array}$ \\
\hline \multicolumn{3}{|l|}{ Modelstatistik: } \\
\hline $\mathrm{N}$ & $\begin{array}{r}2291 \\
023\end{array}$ & $\begin{array}{r}2291 \\
023\end{array}$ \\
\hline F-test & $53,90^{\star * *}$ & $50,09^{* * *}$ \\
\hline
\end{tabular}

Note: OLS-regression. ${ }^{* *}=p<0,001 ; * *=p<0,01, *=0,05$. Ustandardiserede regressionskoefficienter med t-værdier i parentes. Referencekategorien er i begge modeller mandlige studerende fra statskundskab (for model 2 mandlige studerende fra statskundskab med mandlige specialevejledere). 
Diskussion: Hvorfor er det så, at mændene pludselig får bedre karakterer end kvinderne?

Ud fra analyserne kan vi afvise, at mandlige specialevejledere prioriterer deres kvindelige studerende så meget højere, at det resulterer i højere karakterer (det socialpsykologiske argument), ligesom kvindelige vejledere heller ikke lader til at behandle kvindelige specialestuderende dårligere end mandlige specialestuderende (bidronningeargumentet). Der er heller ikke nogen entydig tendens til, at specialevejledere prioriterer de specialestuderende, der kønsmæssigt ligner dem selv (Rip, Rap og Rup-/Kylle, Pylle og Rylle-argumentet). Resultaterne i den eksisterende litteratur er blandede i forhold til betydningen af lærerens/vejlederens demografiske karakteristika (Dee, 2005: 159), men hvis specialekaraktererne anses for at være relativt objektive vurderinger, er vores resultater konsistente med den eksisterende litteratur. Den viser generelt, at lærerens køn ingen eller kun meget begrænset betydning har for objektive testresultater, mens det kan have væsentlig betydning for lærerens subjektive vurdering af den studerende (Evans, 1992; Ehrenberg, Goldhaber \& Brewer, 1995; Dee, 2005).

Det er muligt, at den maskuline dominans på universiteterne især slår igennem ved specialet, om end det taler imod denne tese, at kvinder får de samme specialekarakterer, uanset om de har mandlige eller kvindelige vejledere. Forestillingen om, at maskulinitet på universiteterne generelt skulle gøre opgaver med store krav til selvstændigheden vanskeligere for kvinder, stemmer heller ikke overens med, at Capacent (2007) finder, at en større andel af de kvindelige ph.d.-studerende gennemfører deres ph.d.-uddannelse sammenlignet med de mandlige ph.d.-studerende. Det er derfor yderst relevant at tænke videre over, hvorfor mændene får bedre karakterer end kvinderne i forbindelse med lige specialet.

En mulig forklaring, som vi desværre ikke kan teste her, vedrører forskelle i livssituationen mellem kønnene. Når universitetsstuderende når frem til specialet, er kvinderne måske blevet mere tiltrukket af og forpligtet overfor et voksenliv. Vi ved, at kvinder tidligere end mænd etablerer sig i parforhold, og at kvinder ofte danner par med mænd, der er et par år eller tre ældre end dem selv. ${ }^{3}$ Forklaringen på mændenes bedre karakterer i forbindelse med specialet kunne altså være, at kvindelige specialeskrivere på dette tidspunkt danner par med mænd, som er på arbejdsmarkedet og i gang med en karriere. Desuden ved vi fra mere generelle studier af køn og arbejds-

${ }^{3}$ Jf. Danmarks Statistik (2011) var gennemsnitsalderen for førstegangsviede mænd i 2010 34,6 år og for førstegangsviede kvinder 32,1 år. 
liv, at kvinder begynder at arbejde mindre, når de får børn, mens mænd arbejder mere (Deding \& Filges, 2009). En anden forklaring knytter sig til forskelle i modning og seriøsitet i forhold til studierne. De mandlige studerende er måske "late bloomers" sammenlignet med de kvindelige studerende, og derfor rykker mændene måske mere fagligt i forbindelse med specialet.

Det er også nærliggende at spørge, om kvinderne skulle blive diskrimineret i forbindelse med specialet. Anonymitet er selvsagt ikke en mulighed, hverken i vejledningen eller i bedømmelsen, og måske har såvel kvindelige som mandlige vejledere højere forventninger til de mandlige studerende end til de kvindelige studerende og er dermed umiddelbart mere positivt indstillede, når specialer fra mandlige studerende censureres. Tidligere studier af og eksperimenter vedr. det akademiske peer reviewsystem, karaktergivning på højere læreranstalter samt optagelsesprøver til symfoniorkestre har antydet, at alene forekomsten af kvindenavne kan føre til en strengere bedømmelse (Goldin \& Rouse, 2000; Swim et al., 1989; Budden et al., 2007). Eftersom vi ikke har haft mulighed for at lade de samme specialer bedømme under to forskellige navne, kan vi ikke undersøge dette stringent, men det er alligevel muligt at komme lidt nærmere en besvarelse af spørgsmålet om diskrimination i universitetsbedømmelser. For alle grunddelsfagene på to statskundskabsinstitutter blev karaktererne registreret sammen med de studerendes og bedømmernes køn. I de fleste fag var bedømmelsen anonym. Nogle fag var dog slet ikke anonyme (mundtlig eksamen), mens andre var semi-anonyme (underviserne havde mulighed for at slå de studerendes navne op via deres årskortsnummer, men navnene optræder ikke automatisk). I disse tre typer eksaminer viste der sig ingen forskel på bedømmelsesadfærden (se Andersen \& Salomonsen, 2010, for en nærmere diskussion af undersøgelsen, der hovedsageligt fokuserer på betydningen af bedømmernes køn). Undersøgelsen giver dog langt fra et fyldestgørende belæg for at afvise påstanden om diskrimination i forbindelse med specialeskrivning, bl.a. fordi forskellige eksamensformer påvirker de studerende forskelligt (Andersen \& Tofteskov, 2008), og bedømmelsesprocessen ved grunddelseksaminer adskiller sig fra specialebedømmelsen.

Det er også muligt, at kvindelige specialestuderende bliver diskrimineret i selve vejledningsprocessen, $\mathrm{fx}$ ved at såvel mandlige som kvindelige vejledere har større ambitioner for mandlige studerende og dermed hjælper og udfordre de mandlige studerende mere end de kvindelige. Det må imidlertid være op til fremtidig forskning at undersøge det aspekt. Heldigvis er der begyndt at blive lukket op for specialevejledningens lukkede rum (Jensen, 2010), og vi opfordrer til, at et af emnerne i denne forskningsdagsorden bliver, om mandlige og kvindelige specialestuderende behand- 
les forskelligt. Spørgsmålet om betydningen af kønsforskelle i livssituation og faglig modning fortjener efter vores mening også videre studier.

\section{Konklusion}

Med denne artikel er vi komme lidt nærmere på at få sikker viden om, hvorfor mandlige universitetsstuderende får bedre karakterer end deres kvindelige medstuderende i forbindelse med specialet, når de på den øvrige del af uddannelsen har fået dårligere karakterer. Resultaterne tyder således stærkt på, at det hverken kan forklares med forskelle i, hvad mænd og kvinder studerer, eller med vejledernes køn. Det er tilsyneladende noget ved specialeprocessen eller ved det tidspunkt i de studerendes liv, hvor de skriver speciale, der stiller de mandlige studerende lidt bedre end kvinderne. Forskellene er ikke overvældende store, men det handler stadig om 0,3 karakterpoint, når der er kontrolleret for institut og karaktergennemsnit på den øvrige del af deres universitetsstudium. Det er selvfølgelig ikke sikkert, at resultaterne kan generaliseres fra Aarhus Universitet til resten af universitetsverdenen, men der er modsat heller ikke nogen god grund til, at sammenhængene skulle være anderledes på andre universiteter.

Som specialevejleder kan man klappe sig selv på skuldrene for, at man tilsyneladende ikke lader sit eget køn få indflydelse på kvaliteten af vejledningen, men der er stadig grund til selvransagelse i forhold til den systematiske forskel mellem mandlige og kvindelige specialestuderende. Er man med specialet med til at skabe det første glasloft, som kvinder møder, hvis de ønsker at gøre karriere? Eller skaber de studerende glasloftet for sig selv? Det får vi forhåbentligt flere studier af, efter at denne artikel har aflivet nogle af de mulige forklaringer på, hvorfor de mandlige studerende får bedre specialekarakterer end kvinderne.

Vibeke Lehmann Nielsen er ph.d. og lektor ved Institut for Statskundskab, Aarhus Universitet samt seniorforsker ved det Nationale Forskningscenter for Velfxerd (SFI). Forfatter og medforfatter til en række artikler og bøger om implementering af offentlig politik, regulering og målgruppeadfærd samt offentligt ansattes adfard - herunder blandt andet betydningen af køn for de offentligt ansattes adfard.

Lotte Bøgh Andersen er ph.d. og lektor ved Institut for Statskundskab, Aarhus Universitet samt Anvendt Kommunal Forskning. Hun er forfatter og medforfatter til en række artikler og bøger om offentligt ansattes motivation, adfærd og performance, herunder betydningen af økonomiske incitamenter, professionelle normer, Public Service Motivation og køn.

Michael Bang Petersen er ph.d. og lektor ved Institut for Statskundskab, Aarhus Universitet. Forfatter og medforfatter til en række artikler om forholdet mellem psykologiske processer og politisk adfærd og holdningsdannelse. 


\section{Referencer}

Andersen, H. L., \& Tofteskov, J. (2008). Eksamen og eksamensformer: Betydning og bedømmelse. Frederiksberg: Samfundslitteratur.

Andersen, L. B., \& Salomonsen, H. H. (2010). "Men and women in public organizations. Do they behave differently? And why should they?" Paper presented at EGPA Annual Conference 8 to 10 September, Toulouse, Frankrig.

Andersen, P. T., Bloksgaard, L., \& Christensen, A. (2009). "Magten ved forhandlingsbordet - et mikrosociologisk blik på arbejdsliv", in Tidsskrift for Arbejdsliv, 11(4), 69-84.

Budden, A. E., Tregenza, T., Aarssen, L. W., Koricheva, J., Leimu, R., \& Lortie, C. J. (2007). "Double-blind review favors increased representation of female authors", in Trends in Ecology and Evolution, 23 (1), 4-6.

Buss, D. M. (2011). Evolutionary Psychology: The New Science of the Mind (4th ed.). Boston: Pearson.

Capacent (2007). Undersøgelse af årsager til frafald blandt ph.d.-studerende. København: Epinion Capacent for Universitets- og Bygningsstyrelsen.

http://www.ubst.dk/publikationer/undersogelse-af-arsager-til-frafald-blandtph-d-studerende/Frafaldsanalyse.pdf (tilgået 12. aug. 2011).

Deding, M., \& Filges, T. (2009). Danske lønmodtageres arbejdstid - en registeranalyse baseret på lønstatistikken. København: SFI - Det Nationale Forskningscenter for Velfærd.

Danmarks Statistik (2011) VIE1. "Gennemsnitsalder for viede mænd og kvinder efter alder". http://www.statistikbanken.dk/VIE1 (tilgået 8. dec. 2011).

Dee, T. S. (2005). "A teacher like me: does race, ethnicity, or gender matter?", in The American Economic Review, 95 (2), 158-165.

Ellemers, N., Heuvel, H. V. D., Gilder, D. D., Maass, A., \& Bonvini, A. (2004). “The underrepresentation of women in science: differential commitment or the queen bee syndrome?", in British Journal of Social Psychology, 43 (3), 315-338.

Ehrenberg, R. G., Goldhaber, D. D., \& Brewer, D. J. (1995). “Do teachers' race, gender, and ethnicity matter? Evidence from the National Educational Longitudinal Study of 1988", in Industrial and Labor Relations Review, 48 (3), 547-561.

Evans, M. (1992). “An estimate of race and gender role-model effects in teaching high school" in Journal of Economic Education, 23 (3), 209-217.

Goldin, C., \& Rouse, C. (2000). “Orchestrating impartiality: the impact of "blind" auditions on female musicians" in The American Economic Review, 90 (4), pp. 715-741.

Hasse, C., \& Trentemøller, S. (2008). Break the Pattern! Report from UPGEM (Understanding Puzzles in the Gendered European Map).

http://www.dpu.dk/fileadmin/www.dpu.dk/upgem/publications/subsites upg em 20081111142604 break-the-pattern-viimane.pdf (tilgået 30. nov. 2011).

Højgaard, L. (1996). Køn og løn. København: Samfundslitteratur.

Jensen. H. N. (2010). "Det lukkede rum - en dør på klem til specialevejledning", in Dansk Universitetspædagogisk Tidsskrift, 8, 17-22. 
Johnson, L., Lee, A., \& Green, B. (2000). “The PhD and the autonomous self: gender, rationality and postgraduate pedagogy", in Studies in Higher Education, 25 (2), 135-147.

Ragins B. R., \& Scandura, T. A. (1994). “Gender differences in expected outcomes of mentoring relationships", in The Academy of Management Journal, 37 (4), 957-971.

Staines, G., Tavris, C., \& Jayaratne, T. E. (1974). "The queen bee syndrome" in Psychology Today, 7, 55-60.

Swim, J., Borgida, E., \& Maruyama, G. (1989). “Joan McKay versus John McKay: do gender stereotypes bias evaluations?", in Psychological Bulletin, 105 (3), 409-429.

Wichmann-Hansen, G., Eika, B., \& Mørcke, A. M. (2007). "Hvad findes der af litteratur om vejledning? - Litteratursøgning med fokus på publicerede, evidensbaserede studier", in Dansk Universitetspædagogisk Tidsskrift, 3, 11-19.

Zegers, V. (2004). Man(n) Macht Sprechstunde. Eine Studie zum Gesprächsverhalten von Hochschullehrenden und Studierenden. Bochum: Ruhr-Universität Bochum. http://www-brs.ub.ruhr-unibochum.de/netahtml/HSS/Diss/ZegersVera/diss.pdf (tilgået 11. aug. 2011). 